\title{
MAP SHOWING SURFICIAL GEOLOGY OF THE LATHROP WELLS QUADRANGLE, NYE COUNTY, NEVADA
}

\section{By W C Swadley}




\section{DISCLAIMER}

This report was prepared as an account of work sponsored by an agency of the United States Government. Neither the United States Government nor any agency thereof, nor any of their employees, make any warranty, express or implied, or assumes any legal liability or responsibility for the accuracy, completeness, or usefulness of any information, apparatus, product, or process disclosed, or represents that its use would not infringe privately owned rights. Reference herein to any specific commercial product, process, or service by trade name, trademark, manufacturer, or otherwise does not necessarily constitute or imply its endorsement, recommendation, or favoring by the United States Government or any agency thereof. The views and opinions of authors expressed herein do not necessarily state or reflect those of the United States Government or any agency thereof. 


\section{DISCLAIMER}

Portions of this document may be illegible in electronic image products. Images are produced from the best available original document. 
DEPARTMENT OF THE INTERIOR

UNITED STATES GEOLOGICAL SURVEY

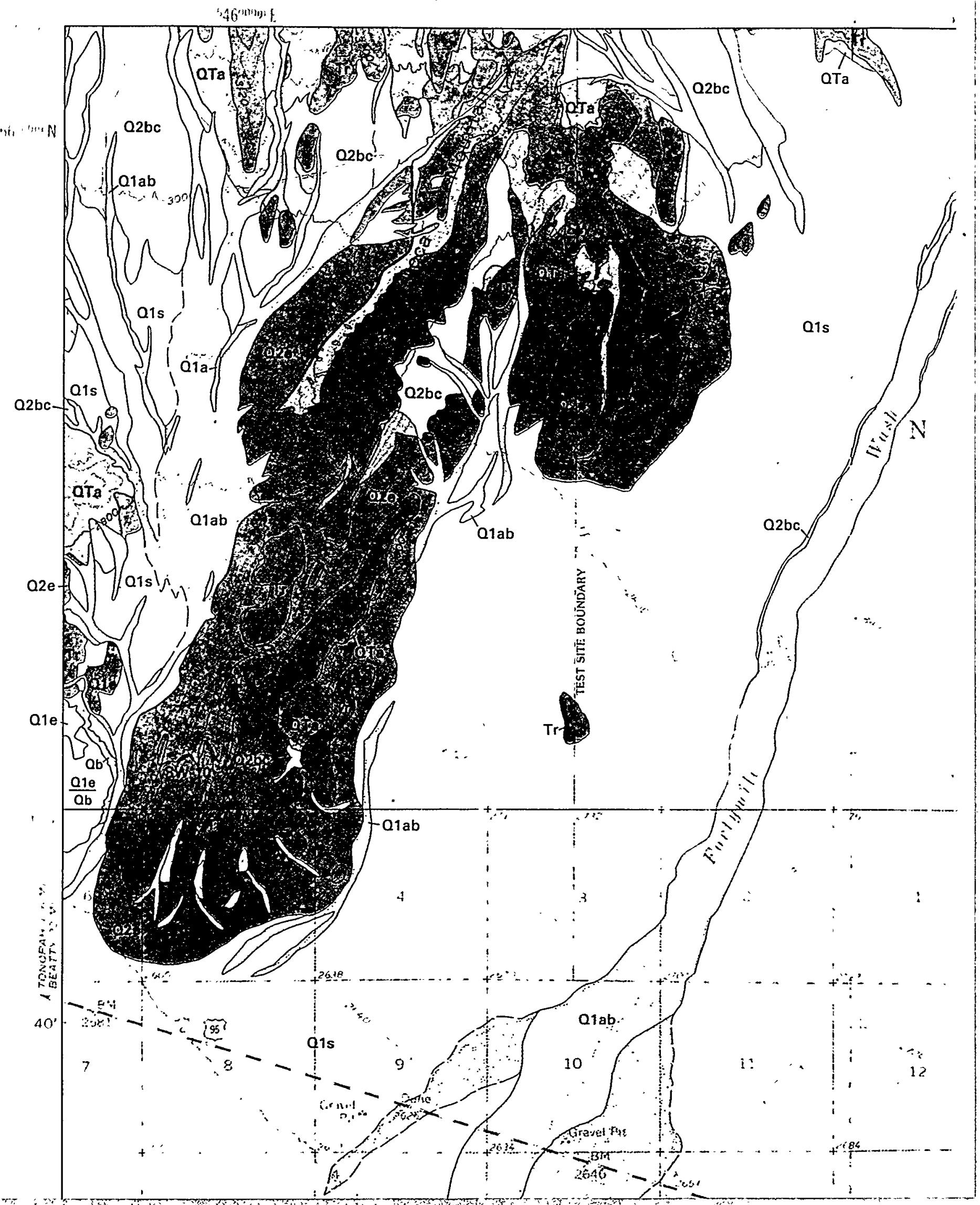




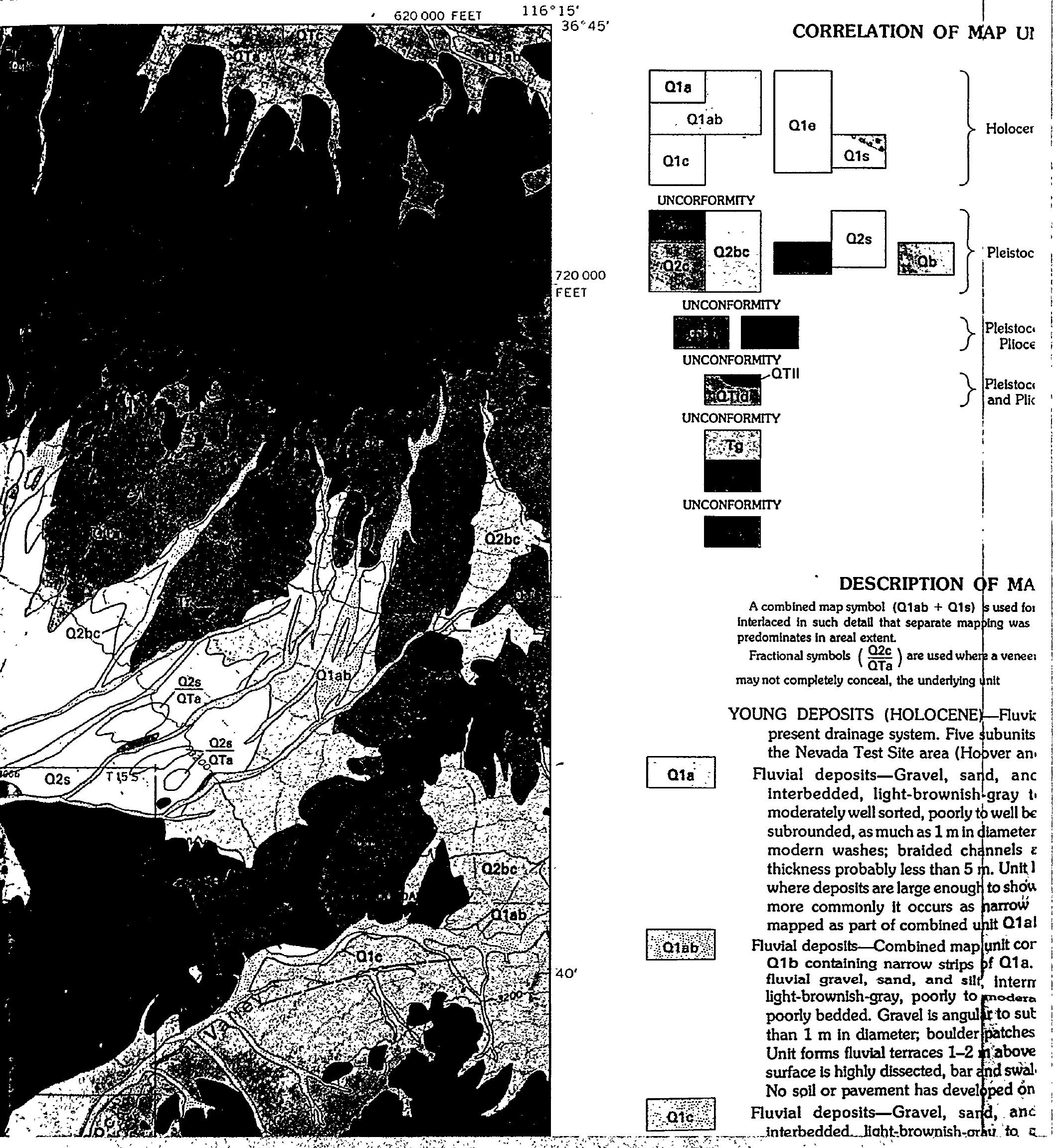




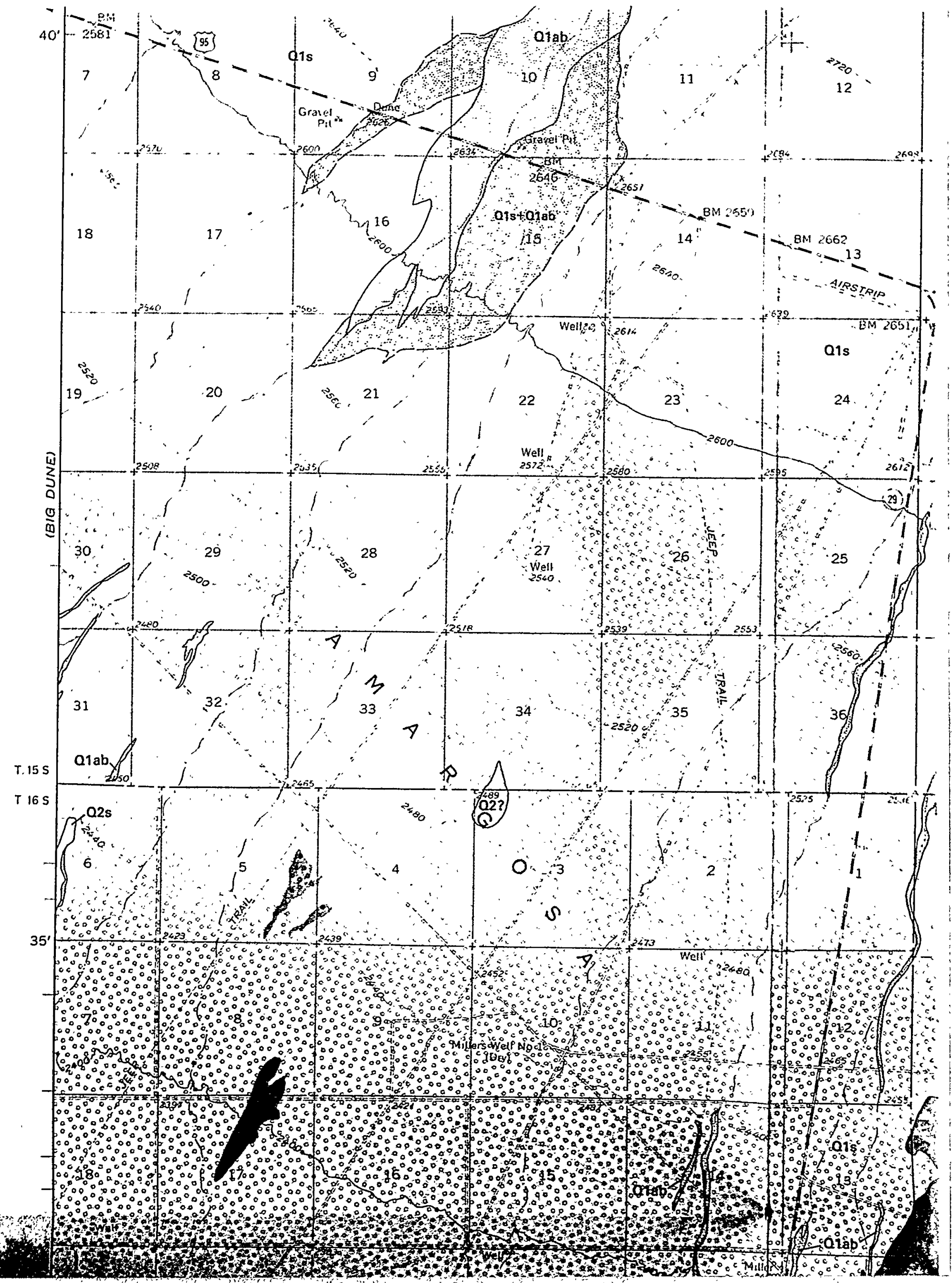




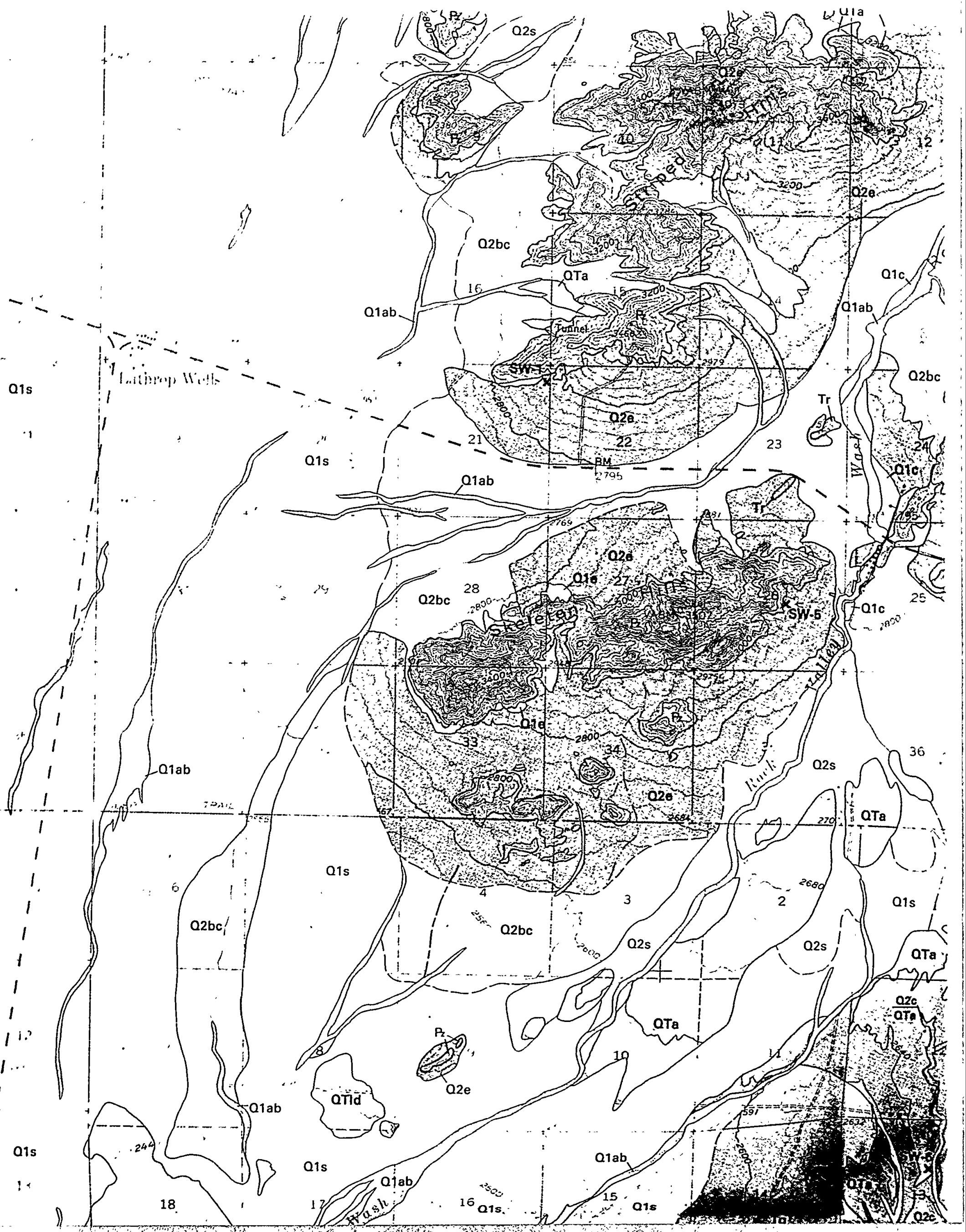




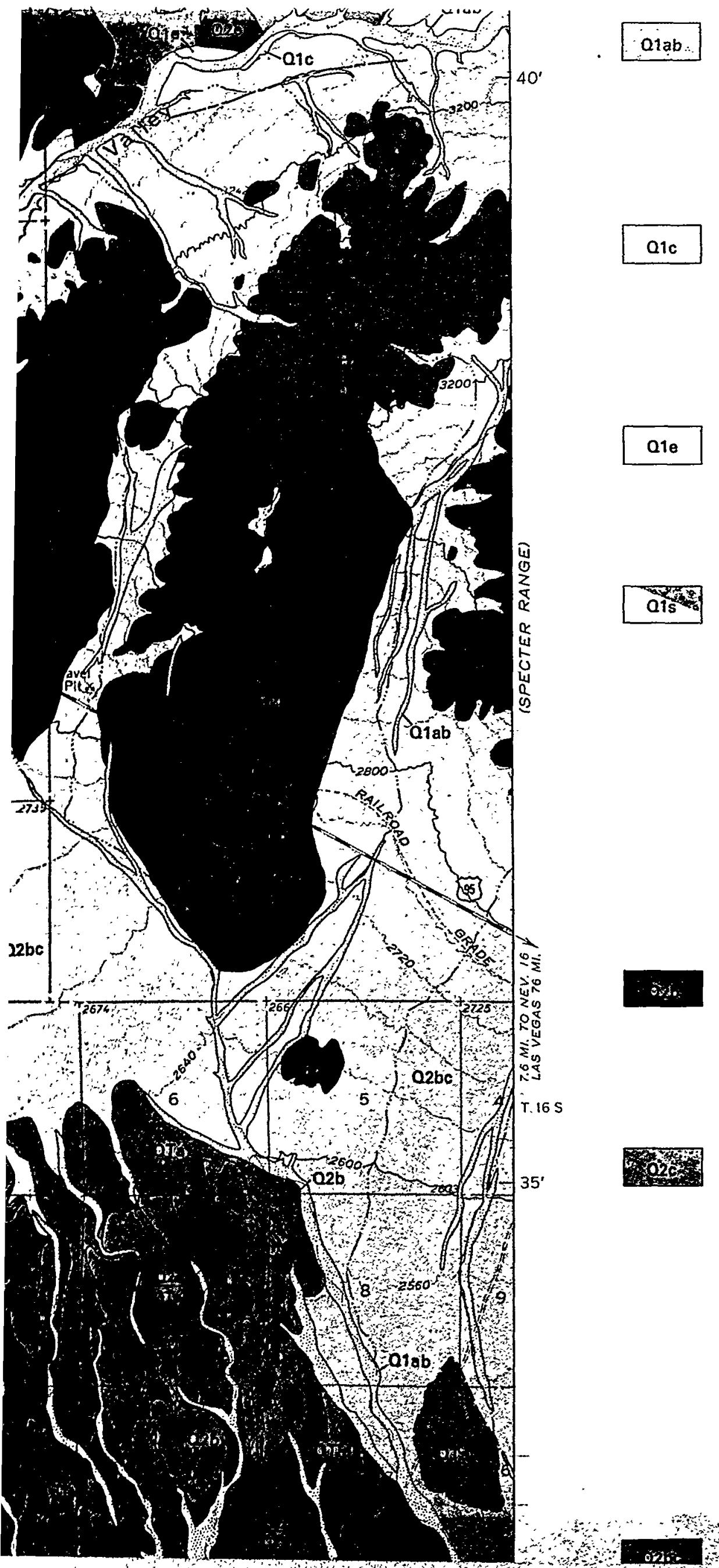

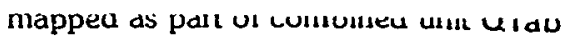

Fluvial deposits - Combined map unit consisting largely of ar Q1b containing narrow strips of Q1a. Q1b deposits con fluvial gravel, sand, and silt, intermixed and interb: light-brownish-gray, poorly to jmoderately well sorted, $u$ poorly bedded. Gravel is angular to subrounded, commor: than $1 \mathrm{~m}$ in diameter; boulder patches and trains are con Unit forms fluvial terraces 1-2 $\mathrm{m}$ above floor of modern $\mathrm{w}$ surface is highly dissected, bar and swale topography is con No soil or pavement has developed on Q1b surfaces

Fluvial deposits-Gravel, sand, and silt, intermixed interbedded, light-brownish-gray to grayish-brown, poc moderately well sorted, moderately well bedded. Gravel is a to subrounded, clasts as much as $1 \mathrm{~m}$ in diameter. Unit terrace remnants along larger drainages and probably un large areas of Q1s along and squth of Fortymile Wash. Sur commonly smooth, in sharp contrast to irregular surface o Soil development consists of thinor carbonate leaching weakly developed $\mathrm{C}$ horizon (stage I of Giles and others,

Eolian deposits-Sand, pale-yellowish-brown to yellowis! fine to medium, moderately well sorted, silty; locally include pebbles and cobbles near bedrock outcrops. Forms small eolian sheets, and vegetation-stabilized mounds; derived from $\mathrm{Q} 1 \mathrm{~s}$ and $\mathrm{Q2e}$ deposits. Unit includes deposits both olc younger than Q1b. Soil development limited to minor car' leaching in older deposits of unit

Fluvial sheet sand deposits-Sand, pale-yellowish-brown, medium, moderately well sorted, silty; contains scattered, and gravel lenses. Unit forms extensive thin sheets coverin! of the western half of the area; surfaces are flat and smoo almost no drainages developed within the sheets. Consists of stream-reworked wind-blown sand. Soll development lin minor carbonate leaching; locally a loosely packed deflatior ment is developed. Unit probably covers large areas of unit Q2c, and QTa; locally overlaps deposits of $\mathbf{0 2 0}$. Gray $t$ dicates areas where sand is moderately to strongly cement. caliche

INTERMEDIATE AGE DEPOSTTS (PLEISTOCENE)-Include: and eolian units. Unit has been subdivided in the Nevada $T$ area into five subunits based on lithology, geomorp: depositional environment, and soil development (Hoos. others, 1981); one subunit ( 02 a) has not been recognizer quadrangle

Fluvial deposits-Gravel, sand, and silt. Gravel, yellow grayish-brown, poorly to moderately well sorted, poorly bedded; clasts commonly less than $0.5 \mathrm{~m}$. Sand and silt c matrix of gravel and as sand and gravelly sand beds anc interbedded with gravel. Unit occurs as terraces alon! washes cut into Q2C surfaces and as the lower parts of allui below bedrock hills; forms smooth slopes. Fan deposits upslope into unit Q2C

Fluvial deposits-Gravel, sand, and silt. Gravel, yellowish- to brown, poorly to moderately well sorted, nonbedded to wellincludes boulders commonly $0,5 \mathrm{~m}$ in diameter, rarely than $1 \mathrm{~m}$. Sand and silt occur in gravel matrix and: and gravelly sand beds and lenses within gravel, Unit vers to $\mathrm{Q2b}$ except for topographio position and soll devek Forms the middle and upper parts of extensive fans di on and downslope from QTa fans; merges downslope wr. fans. Solls developed on Q2c vafy from a well-developed $k$ 1-2 $\mathrm{m}$ thick to a moderately developed $\mathrm{C}$ horizon $0.5-1$ (stage IV and stage III, respectively, of Giles and others, overlain by a $B$ horizon that varies from silicified reddk' argillic to a light-brown cambic, and which is overlain by brownish-gray vesicular slitand clay $A$ horizon. Desert pi developed on a2c is commong densely packed, moder well sorted, and has a well-devy pped black vamish. Unit d by both debris-flowind flagy thepostion; reported to be 1 os 65 m thick in dintholes

Fuvitardeposits:Combined map unit consisting of Q2c all 
It occurs as narrow strips within $Q 1 \mathrm{~b}$ and is combined unit $Q 1 \mathrm{ab}$

ombined map unit consisting largely of areas of larrow strips of Q1a. Q1b deposits consist of and, and silt, Intermixed and interbedded, $y$, poorly to moderately well sorted, well to ravel is angular to subrounded, commonly less eter, boulder patches and trains are common. terraces 1-2 m above floor of modern washes; issected, bar and swale topography is common. ent has developed on Q1b surfaces

Gravel, sardd, and silt, intermixed and t-brownish-gray to grayish-brown, poorly to irted, moderately well bedded. Gravel is angular lasts as much as $1 \mathrm{~m}$ in diameter. Unit forms along larger drainages and probably underlies i along and squth of Fortymile Wash. Surface is 1 , in sharp contrast to irregular surface of Q1b. consists of minor carbonate leaching and a C horizon (stage I of Giles and others, 1966) and, pale-yellowish-brown to yellowish-gray, oderately well sorted, silty; locally includes a few les near bedrock outcrops. Forms small dunes, I vegetation-stabilized mounds; derived in part deposits. Unit includes deposits both older and 1. Soil development limited to minor carbonate deposits of unit deposits-Sand, pale-yellowish-brown, fine to ely well sorted, silty; contains scattered pebbles Unit forms extensive thin sheets covering much f of the area; surfaces are flat and smooth with es developed within the sheets. Consists largely d wind-blown sand. Soll development limited to aching; locally a loosely packed deflation pave. Unit probably covers large areas of units $01 \mathrm{c}$, scally overlapp deposits of Q2e. Gray tone ine sand is moderately to strongly cemented with

DEPOSITS (PLEISTOCENE)-Includes fluvial Init has been subdivided in the Nevada Test Site bunits based on lithology, geomorphology, onment, and soil development (Hoover and subunit (Q2a) has not been recognized in this

ravel, sand, and silt. Gravel, yellowish- to orly to moderately well sorted, poorly to well amonly less than $0.5 \mathrm{~m}$. Sand and silt occur as nd as sand and gravelly sand beds and lenses gravel. Unit occurs as terraces along some icsurfaces and as the lower parts of alluvial fans 15 , forms smooth slopes. Fan deposits merge D2C

vel, sand, and silt. Gravel, yellowish- to grayishoderately well sorted, nonbedded to well-bedded; commonly $0.5 \mathrm{~m}$ in diameter, rarely greater and silt occur in gravel matrix and as sand beds and lenses within gravel. Unit very similar $r$ topographig position and soll development. and upper parts of extensive fans deposited from QTa fans; merges downslope with Q2b id on $\mathrm{Q} 2 \mathrm{c}$ vary from a well-developed $\mathrm{K}$ horizon noderately developed $\mathrm{C}$ horizon $0.5-1 \mathrm{~m}$ thick e III, respectively, of Giles and others, 1966); orizon that varies from silicified reddish-brown own cambic, and which is overlain by a lightzular silt and clay $A$ horizon. Desert pavement : is commonly densely packed, moderately to s a well-devebped black varnish. Unit deposited and fluvial deposition; reported to be as much
Colluvium-Kubble, angular pebble- to boulder-size fragments, very poorly sorted, nonbedded, locally cemented with caliche. Forms talus deposits along base of steep slopes developed on Tertiary volcanic rocks at Little Skull Mountain

\section{LACUSTRINE DEPOSITS (PLEISTOCENE? AND PLIOCENE)}

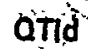

Marl-Pale-yellowish-brown, weathers white to very light gray; silty, soft, plastic when wet; consists of calcite, quartz silt, sand-sized rock fragments and clay; includes several thin limestone beds as much as $1 \mathrm{~m}$ thick. Poorly exposed; locally covered by a lag of limestone rubble; many areas of lacustrine deposits partly masked by thin, discontinuous cover of wind-blown sand. Age and stratigraphic position of unit not well known; some outcrops overlain unconformably by QTa; at south end of bedrock hills near south-central border, unit includes a Pearlette-type ash bed dated at more than 800,000 years B.P. (J. N. Rosholt, written commun., 1979) based on its thorium content

Limestone-White to light-gray, weathers white to very light gray; finely crystalline, hard; locally includes sand and small pebbles; weathers to a very rough, pitted surface. Maximum exposed thickness about $3.5 \mathrm{~m}$ near south edge of quadrangle; thins northward to a feather edge. Unit forms resistant caps on several flat-topped ridges underlain by marl in southeast quarter of the quadrangle

FLUVIAL GRAVEL (TERTIARY)-Gravel, subrounded to well-rounded, poorly sorted; silty, sandy matrix, locally well cemented with caliche; includes well-rounded boulders as much as $0.6 \mathrm{~m}$ in diameter, largely quartzite and argillite with lesser amounts of limestone, dolomite, and volcanic and plutonic rocks. Unit poorly exposed, forms a low ridge in southeast part of area that is largely masked by $\mathrm{Q2}$ (?) sand and a lag of reworked Tg gravel. Best exposure is in cutbank of small wash at northwest edge of area of $\mathrm{Tg}$

TERTIARY ROCKS-Undivided rocks of Tertiary age that include welded and nonwelded tuffs, basalt flows, and minor amounts of conglomerate, sandstone, and limestone. Tertiary rocks of the quadrangle are described by Burchfiel (1966), Sargent and others (1970), and McKay and Sargent (1970). Small areas of previously unmapped Tertiary(?) rocks in the southeast quarter of the area consist of black scoriaceous to dense basalt flows; in part overlain by unit QTa

PALEOZOIC ROCKS (DEVONIAN TO PRECAMBRIAN)-Undivided rocks of Paleozoic and Precambrian age including dolomite, limestone, quartzite, siltstone, and minor amounts of chert and shale. Formations of the quadrangle mapped and described by Burchfiel (1966) and Sargent and others (1970)

\section{CONTACT_Dashed where approximately located}

I FAULT-Dashed where inferred; dotted where concealed. Ball and bar on downthrown side

LINEAMENT_Probably fault related

AREAS OF ABUNDANT FRAGMENTS OF CALCIFIED VEGETAL MATS-Probably deposited in marsh areas

x SW-6 SAMPLE LOCALITY-Pliocene or Pleistocene silicic ash bed

\section{REFERENCES CITED}

Burchfiel, B. C., 1966, Reconnaissance geologic map of the Lathrop Wells 15-minute quadrangle, Nye County, Nevada: U.S. Geological Survey Miscellaneous Geologic Investigations Map I-474, scale 1:62,500.

Giles, L. H., Peterson, F. F., and Grossman, R. B., 1966, Morphological and genetic sequences of carbonate accumulations in desert solls: Soll Science, v. 101, no. 5 , 347-360.

Hoover, D. L., Swadley, W C, and Gordon, A. J., 1981, Correlation of Quatemary alluvial fan deposits in the Nevada Test Site area: U.S. Geological Survey OpenFile Report 81-512, 27p.

Marvin, R. F., and Cole, J. C., 1978, Radiometric

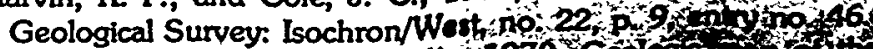

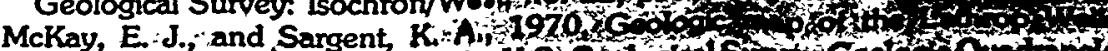

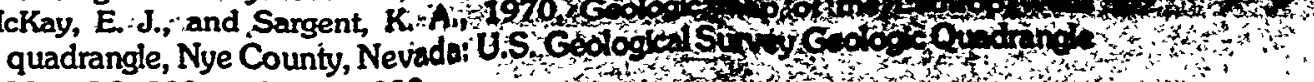




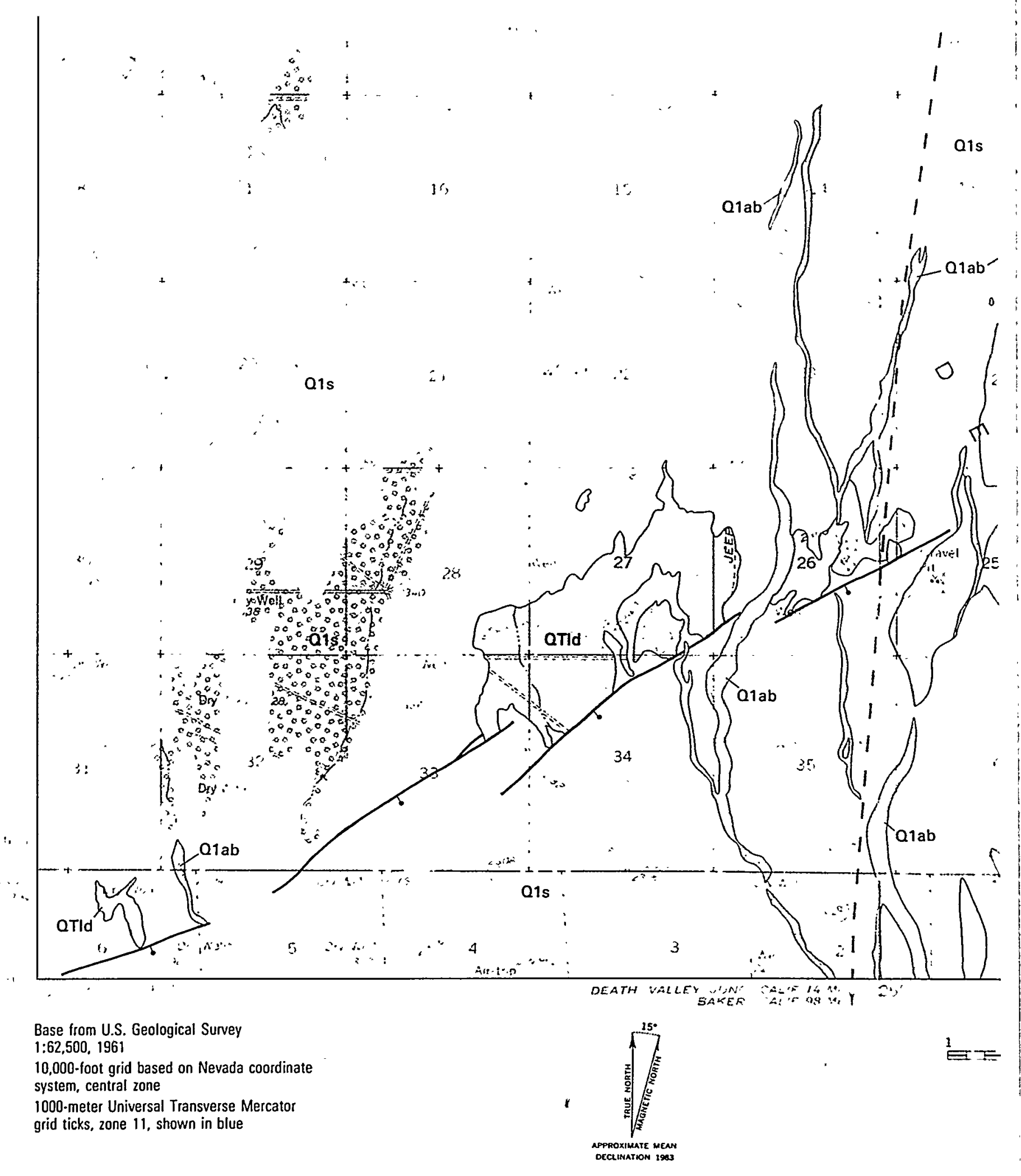

\section{MAP SHOWING SURFICIAL GEOLOGY (}




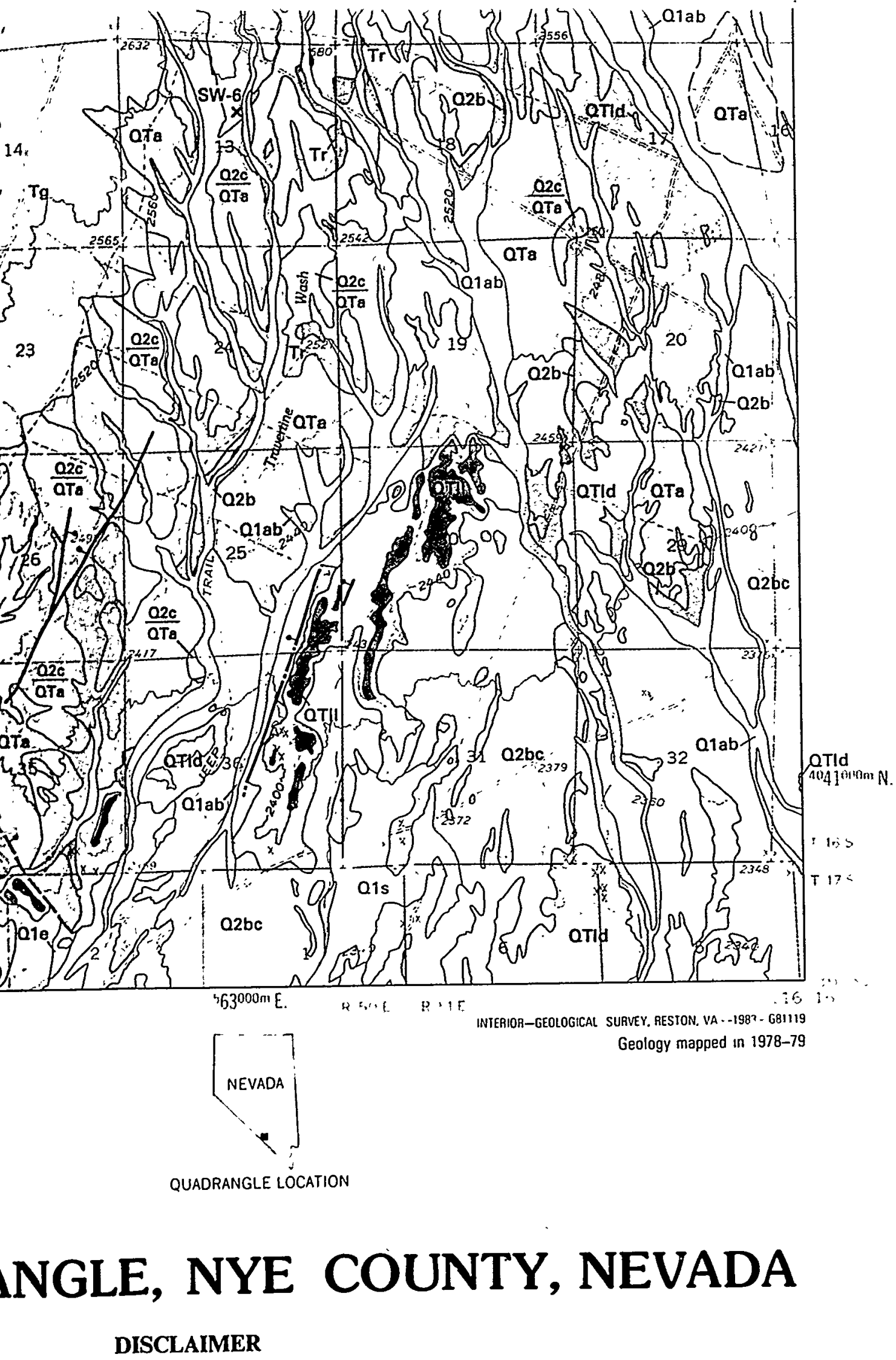

a2bc

$1-2 \mathrm{~m}$ thick to a moder (stage IV and stage III, , overlain by a $\mathrm{B}$ horizon argillic to a light-brown c brownish-gray vesicular s developed on $\mathrm{O} 2 \mathrm{C}$ is $\mathrm{cc}$ well sorted, and has a we by both debris-flow and t as $65 \mathrm{~m}$ thick in drill

Fluvial deposits-Combint and terrace deposits th terrace deposits

TABLE 1.-IDENTIF

\begin{tabular}{|c|c|c|}
\hline $\begin{array}{c}\text { Sample } \\
\text { No. }\end{array}$ & Location & k \\
\hline $\begin{array}{l}\text { SW-1 } \\
(79 G 4)^{1}\end{array}$ & Striped Hills & \\
\hline $\begin{array}{l}\text { SW-5 } \\
(79 W 61)^{1}\end{array}$ & Skeleton Hills & \\
\hline $\begin{array}{l}\text { SW-6 } \\
(79 W 67)^{1}\end{array}$ & Travertine Wash. & 1 \\
\hline SW-9 & SE Yucca Mtn. & $\begin{array}{l}\text { Co } \\
\text { Fre }\end{array}$ \\
\hline SW-10 & SW Yucca Mtn. & $\begin{array}{l}\text { Prot } \\
\text { Fla }\end{array}$ \\
\hline $\begin{array}{l}\text { TSV-194 } \\
(79 W 68)^{1}\end{array}$ & Fairbanks Hills & $\mathrm{P}$ \\
\hline
\end{tabular}

1Sample number assigned by $G$. Izett. 2Not yet analyzed as of Sept. 1980.

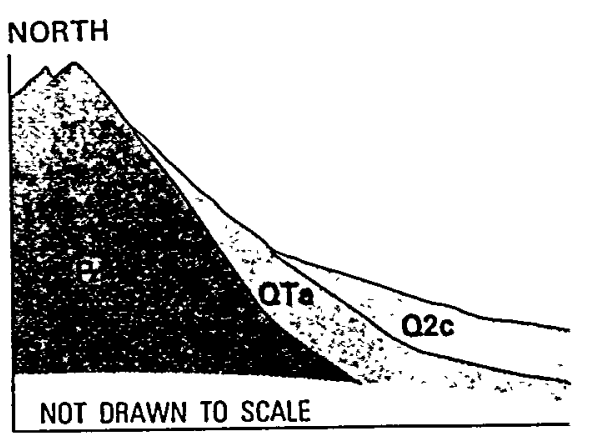

FIGURE 1-H

ared as an account of work sponsored by an agency of the United States er the United States Government nor any agency thereof, nor any of their y warranty, express or implied, or assumes any legal liability or responsicy, completeness, or usefulness of any information, apparatus, product, or represents that its use would not infringe privately owned rights. Referpecific commercial product, process, or service by trade name, trademark. herwise does not necessarily constitute or imply its endorsement, recoming by the United States Government or any agency thereof. The views thors expressed herein do not necessarily state or reflect those of the nment or any agency thereof. 
QTa fans; merges downslope with $Q 2 b$ Q2c vary from a well-developed $\mathrm{K}$ horizon ately developed $\mathrm{C}$ horizon $0.5-1 \mathrm{~m}$ thick respectively, of Giles and others, 1966): that varies from sillcified reddish-brown cambic, and which is overlain by a lightsilt and clay $A$ horizon. Desert pavement ommon'y densely packed, moderately to ell-developed black vamish. Unit deposited fluvial deposition; reported to be as much holes

ed map unit consisting of $\mathrm{Q} 2 \mathrm{c}$ alluvial fan lat grade downslope into $Q 2 \mathrm{~b}$ fan and
Giles, L. H., Peterson, F. F., and Grossman, R. B., 1966, Morphological and genetuc sequences of carbonate accumulations in desert soils. Soil Science, v. 101, no. 5, 347-360.

Hoover, D. L., Swadley, W C, and Gordon, A. J., 1981, Correlation of Quatemary alluvial fan deposits in the Nevada Test Site area: U.S. Geological Survey OpenFile Report 81-512, 27p.

Marvin, R. F., and Cole, J. C., 1978, Radiometric ages: Compilation A, U.S. Geological Survey: Isochron/West, no. 22, p. 9, entry no. 46.

McKay, E. J., and Sargent, K. A., 1970, Geologic map of the Lathrop Wells quadrangle, Nye County, Nevada: U.S. Geological Survey Geologic Quadrangle Map GQ-883, scale 1:24,000.

Sargent, K. A., McKay, E. J., and Burchfiel, B. C., 1970, Geologic map of the Striped Hills quadrangle, Nye County, Nevada: U.S. Geological Survey Geologic Quadrangle Map GQ-882, scale 1:24,000.

FICATION OF ASH BEDS IN LẠTHROP WELLS QUADRANGLE, NYE COUNTY, NEVADA

\begin{tabular}{|c|c|c|c|}
\hline Identification & $\begin{array}{l}\text { Age } \\
\text { (yrs.) }\end{array}$ & Stratigraphic position & Remarks \\
\hline Bishop ash & 700,000 & $\begin{array}{l}\text { Underlain by Cambrian rocks; overlain by } \\
\text { intermediate sand (unit } \mathrm{Q} 2 \mathrm{e} \text { ). }\end{array}$ & $\begin{array}{l}\text { Identified by G. Izett (oral commun., } \\
\text { 1979). }\end{array}$ \\
\hline Bishop ash & 700,000 & $\begin{array}{l}\text { Within intermediate eolian sand (unit } \\
\text { Q2e). }\end{array}$ & $\begin{array}{l}\text { Identified by G. Izett (oral commun., } \\
\text { 1979). }\end{array}$ \\
\hline Unidentified & Quaternary & Within intermediate alluvium (unit $\mathrm{Q} 2 \mathrm{c}$ ). & $\begin{array}{l}\text { Ash altered. Zircon separate contaminated } \\
\text { with Tertiary and Mesozoic age zircons. } \\
\text { Biotite separate gave Miocene age } \\
\text { (Marvin and Cole, 1978). }\end{array}$ \\
\hline $\begin{array}{l}\text { orrelated with } \\
\text { enchman Flat ash } \\
\text { bed (lzett, written } \\
\text { Comm un.. } \\
\text { 1981) }\end{array}$ & 2.2 million & $\begin{array}{l}\text { Underlain by Tertiary volcanics; overlain } \\
\text { by intermediate eolian sand (unit Q2e), } \\
\text { adjacent to extensive area of eolian sand } \\
\text { (unit } \mathrm{Q2e} \text { ). }\end{array}$ & $\begin{array}{l}\text { Identified by Izett (written commun., 1981) } \\
\text { Similar to Bishop ash but age is } 2.2 \text { m.y. by } \\
\text { fission track on Frenchman Flat ash (izett, } \\
\text { written Commun., 1981) }\end{array}$ \\
\hline $\begin{array}{l}\text { bably Frenchman } \\
\text { lat ash bed }\end{array}$ & 2.2 million? & $\begin{array}{l}\text { Underlain by Tertiary volcanics; overlain } \\
\text { by colluvium; adjacent to intermediate } \\
\text { eolian sand (unit } \mathrm{Q} 2 \mathrm{e} \text { ). }\end{array}$ & $\begin{array}{l}\text { Not identified, but similar to } S W-9 \text { in } \\
\text { appearance }\end{array}$ \\
\hline $\begin{array}{l}\text { Possibly older } \\
\text { Pearlette ash }\end{array}$ & Quaternary(?) & $\begin{array}{l}\text { Within lake deposits of Pleistocene (?) } \\
\text { and Pliocene age (unit QTId). }\end{array}$ & $\begin{array}{l}\text { Thorium content appropriate for } \\
\text { Pearlette-type "B" or "S" ash (J. N. } \\
\text { Rosholt, written commun., 1979), but } \\
\text { could be one of several other ash beds. }\end{array}$ \\
\hline
\end{tabular}

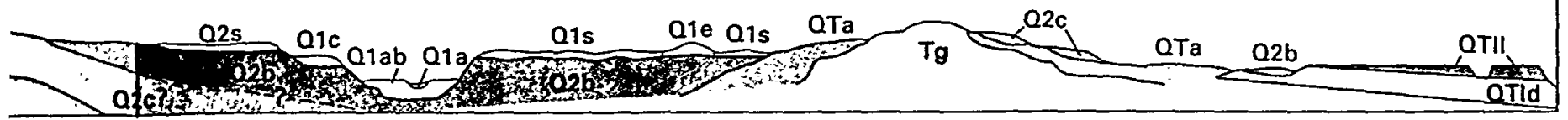

